\title{
O corpo e a voz, a língua e a cidade: carne e pedra na constituição das subjetividades do tempo presente
}

\section{The body and the voice, language and city: Meat and stone in the constitution of subjectivitys in the present time}

\author{
Carlos PIOVEZANI \\ Universidade Federal de São Carlos (UFSCar) \\ Allice Toledo Lima da SILVEIRA \\ Universidade Federal de São Carlos (UFSCar) \\ Joseane Silva BITTENCOURT \\ Universidade Federal de São Carlos (UFSCar)
}

\begin{abstract}
Resumo: O presente artigo objetiva refletir sobre as subjetividades contemporâneas que se dão a ver na/pela mídia e na/pela cidade no que tange ao controle das representações do corpo e dos usos da língua. À luz dos postulados de Michel Foucault, principalmente àqueles que concernem sobre as condições históricas de possibilidades pelas quais passaram as sociedades de soberania para as disciplinares e, por últimas, as sociedades de controle, incidiremos nossa discussão sobre o funcionamento e a circulação midiática de discursos do "bem falar" e do bem escrever; discursos sobre a beleza, boa forma e bem-estar, aos quais relacionaremos com as práticas e os discursos urbanísticos que produzem também suas formas de controle, a fim de delinear um esboço do movimento de gestão social que descarta e agrega, privilegia e segrega, quando se trata de língua, de corpo e de cidade. Articularemos ainda às nossas discussões algumas passagens do texto "Delimitações, inversões, deslocamentos", de Michel Pêcheux, que abordam algumas questões sobre a injunção entre o ver e o dizer e a forma como se aliam os projetos urbanos e as políticas linguísticas de algumas sociedades. Assim, as três dimensões tratadas neste trabalho - corpo, língua e espaço - são tomadas como materialidade simbólica para entender a própria constituição "humana" do homem, da sua subjetividade e de sua cidadania.
\end{abstract}

Palavras-chave: Língua; Discurso; Corpo; Cidade.

\begin{abstract}
This article aims to reflect on contemporary subjectivities that are given to do in / by the media and in / around town regarding the control of representations of body and language usage. According to the postulates of Michel Foucault, especially those that concern about the historical conditions of possibility regarding the shift of sovereign societies to disciplinary societies and societies of control, we will emphasize our discussion on the functioning and the media circulation of discourses concerning the ability to speak and write well; discourses about beauty, fitness and wellness, which will relate to the practices and the urban discourse which also produce their forms of control in order to delineate an outline of social management movement that rules and adds, privileges and segregates, when it comes to language, body and city. We will also add to our discussions some passages of the text "Delimitações, inversões, deslocamentos" written by Michel Pêcheux that address some questions about the injunction between seeing and saying and the way they combine the urban projects and language policies of some societies. Thus the three dimensions considered in this work - body language and space - are taken as symbolic materiality to understand the"human" constitution of man, of his subjectivity and citizenship.
\end{abstract}

Keywords: Language; Discourse; Body; City 


\title{
Introdução
}

\author{
A cidade é moderna/ dizia o cego a seu filho \\ os olhos cheios de terral o bonde fora dos trilhos \\ a aventura começa no coração dos navios \\ pensava o filho calado/ pensava o filho ouvindo \\ que a cidade é moderna/ pensava o filho sorrindo \\ e era surdo e era mudo/ mas que falava e ouvia. \\ Milton Nascimento e Ronaldo Bastos
}

A música Trastevere, de Milton Nascimento e Ronaldo Bastos, ilustra bem as relações humanas contemporâneas, engendradas pelas condições de possibilidades de seu tempo histórico, e atravessadas, no entanto, por diversas crenças e valores, ritos e práticas, (des)ordens e controles, memórias e esquecimentos, e ideologias conflitantes. Cidades de carne e de pedra: o espaço que se preenche e se esvazia, o concreto que se ergue e se erode, o corpo que se modela e se disforma, as imagens que se proliferam e se rarefazem, e ainda o verbo que se multiplica, ecoa e se emudece. Da Idade Média aos tempos (pós-)modernos; da "langue de bois" para a "langue de vent": a história, ao mesmo tempo, quase sem nenhuma mudança e tão repleta delas. O "indizível", o "invisível", o "impensado" e o "inexistente" de cada tempo-espaço: condições de possibilidade do dizer, do ver, do pensar e do existir. É a partir daí que, com vistas a refletir sobre a produção de subjetividades do tempo presente, conforme os postulados de Michel Foucault, na/pela mídia e na/pela cidade, no que concerne ao controle das representações e dos usos da língua e do corpo, e, ainda, no que respeita ao movimentopreenchimento no espaço urbano, pretendemos aventar algumas hipóteses que tangenciam tanto o funcionamento de discursos quase onipresentes nos veículos midiáticos brasileiros da nossa contemporaneidade, quais sejam, aqueles dos "bons conselhos", das "dicas", sobretudo, referentes ao (bom) uso da língua e à (boa) forma do corpo, quanto a ocupação do e a circulação no espaço urbano. De fato, o escopo de nosso trabalho incide sobre a especificidade do fenômeno midiático da difusão maciça dos discursos do "bem falar" e do "bem escrever", e daqueles da beleza, da boa-forma e do bem-estar do corpo, aos quais relacionaremos alguns discursos/práticas urbanísticos (aqueles do fechamento urbano: grades, muros, condomínios fechados), com o intuito de traçar um esboço do semelhante movimento de gestão social que contempla e descarta, que privilegia e segrega, quando se trata de língua, de corpo e de cidade.

Salientamos que a possibilidade de abranger as discursividades desses três domínios, quanto às suas representações e às suas práticas, advém do fato de se poder concebê-los semiologicamente, com base nos escritos arqueológico-foucaultianos, no interior dos quais se pode vislumbrar uma "teoria do discurso" ou "da linguagem", conforme perseverantemente atesta Maria do Rosário Gregolin, ou, ainda, na esteira de Courtine (1989), onde se pode entrever uma espécie de "semiologia histórica". Daí decorre que neste trabalho o método e a teoria arqueológico-discursiva estejam tão implicitados quanto pulverizados e onipresentes, uma vez que por seu intermédio tornase possível transcender o "a-" ou o "anti-" historicismo próprio das semiologias estruturalistas.

Faremos, tendo em vista nossos objetivos, uma sintética recensão, perpassada por comentários e por aportes históricos, de alguns pontos de um prodigioso texto de Michel Pêcheux, "Delimitações, Inversões, Deslocamentos", que aponta para a inerência entre o ver e o dizer, para o modo como se coadunam os projetos urbanos e as políticas linguísticas em algumas sociedades ocidentais. A partir da reflexão nele contida, que se estende das sociedades feudo-monárquicas até os regimes autoritários, 
com modo de produção socialista, do século XX, levantamos, como já dissemos, algumas conjecturas sobre como se dão essas relações entre as edificações urbanas e o controle dos usos linguísticos e dos embelezamentos do corpo, no final do século passado e início deste, ou seja, na "sociedade do controle". São, aqui, fundamentais as referências que trazemos de Michel Foucault, principalmente suas elucubrações acerca das passagens históricas das sociedades de soberania, para as de disciplinas, e dessas últimas para as de controle.

\section{Modos de ver e de sentir: fronteiras, corpos, muralhas e normas}

Segundo Richard Sennett (2003), a inércia das relações sociais até a Idade Média assentava-se no antigo princípio "fisiológico" hipocrático do calor do corpo. Desde a Antiguidade Clássica, o ardor corporal era índice por meio do qual eram distintos cidadãos e escravos, gregos e bárbaros, homens e mulheres; nas Monarquias-feudais, o nobre já nascia diferenciado, seu sangue era azul e seu corpo era quente. Ao tomar a Idade Média como ponto de partida, Pêcheux também observa essa rigorosa imobilidade nas relações sociais, sob a forma de nítidas fronteiras que separam nobres e plebeus; do lado dos primeiros, os muros, os fossos, os castelos e o latim; dos últimos, as cercas frágeis, simbólicas, ou até mesmo sua elisão, as casas simples e os falares vulgares. De modo recíproco e coextensivo, as barreiras e demarcações vão da arquitetura para a língua e da língua para a arquitetura, conforme ratificam os seguintes excertos:

As ideologias feudais supunham a existência material de uma barreira linguística que separava aqueles que, por seu estado, eram os únicos suscetíveis de entender claramente o que tinham a se dizer, e a massa de todos os outros, tidos como inaptos para se comunicar realmente entre si, e a quem os primeiros só se endereçavam pela martelação retórica da religião e do poder. (PÊCHEUX, 1990, p. 09-10)

As táticas de distanciamento por meio da construção de uma barreira visível constituem uma das características principais do dispositivo feudal: Regis Debray evocou recentemente este momento do século XII em que a "arquitetura feudal eleva as muralhas, escava ainda mais os fossos - o poder supremo está nos castelos. No século XIII, a arquitetura religiosa idealiza tribunas, estalas e coros separados, para isolar melhor o clero da multidão dos laicos. O corpo eclesiástico reforça sua clausura no momento em que a apoteose teocrática dá à Igreja o poder supremo" (Le scribe, p. 23-24). O interesse para nós está no que Debray acrescenta: "As necessidades da administração reestabelecem o uso da escrita. O latim é restaurado como instrumento de comunicação "internacional", comum à Igreja e à chancelaria. Os reis e os príncipes serão os únicos, juntamente com os cléricos, que poderão aprendê-lo. As falas vernaculares se convertem em "línguas vulgares", que são abandonadas ao povo - maneira de demarcar dirigentes e dirigidos" (ibid., p. 25). O latim seria assim a "língua de madeira" da ideologia feudal, realizando ao mesmo tempo a comunicação e a não-comunicação. (PÊCHEUX, 1990, p. 20-21)

Assim, instaura-se uma cisão do mundo feudal em "dois mundos", assegurada por visíveis delimitações arquiteturais e por expressos limites linguísticos: monumentos 
de pedra e línguas de madeira - a imobilidade e a rigidez das formas encarnam a imobilidade social. Além disso, os dois mundos eram ainda divididos pela diferença dos corpos: a maior estatura do corpo do nobre, frente ao corpo plebeu, era reforçada pelos tipos e cores dos tecidos e pelos trajes volumosos, opulentos e suntuosos. Entretanto, essa partição não se sustentava sem o fundamento advindo da necessária presença (ausente) de um "terceiro mundo" invisível, no qual não há separação, sendo "todos iguais perante Deus": "a ideologia religiosa, que dominava a formação sócio-histórica, feudal e monárquica, consistia essencialmente em administrar esta relação com o 'alhures' que a funda; ela representava este 'alhures', tornando-o visível através das cerimônias e das festas - inscrevendo aí os discursos - que colocavam em cena este corpo social unificado, radioso, transfigurado, que manifesta o "inexistente constitutivo" da sociedade feudal" (PÊCHEUX, 1990, p. 10).

Le Goff e Troung (2011) também demarcam o uso do corpo como metáfora na Idade Média, herança de uma tradição aristotélica que pensava o corpo cujo sistema funcional caput-venter-membra (cabeça-entranhas-membros) designava também as funções dos indivíduos em uma sociedade. As partes do corpo respondiam ao uso político de suas funções: o alto do corpo, a cabeça, por exemplo, representava o monarca e/ou o clero; os membros, a plebe, os trabalhadores; e as partes baixas, como as entranhas, simbolizavam geralmente as paixões, algo que deveria ser controlado para que se mantivesse a ordem e a saúde de todo o corpo social. A utilização política da metáfora corporal é lembrada também por Ernst Kantorowicz (1998) em seu estudo sobre a teologia política medieval, cujo mote principal é a teoria dos dois corpos do rei, a partir da qual os juristas elisabetanos elaboravam suas definições da realeza e das capacidades mentais. Tal teoria postulava a ideia de que o rei era constituído de dois corpos: um natural, portanto, sujeito às falhas e intempéries do tempo e da vida; e um corpo político, "vazio de Infância e Velhice e de outros Defeitos e Imbelicidades naturais" (KANTOROWICZ, 1998, p. 22). Desse modo, a imortalidade da dignidade real do seu corpo político aliada à sucessão dinástica e ao caráter corporativo da Coroa são os princípios da perpetuidade e da totalidade do corpo político de um rex qui nunquam moritur.

Todavia, o divino dominante tende a ter sua predominância mitigada, visto que nos crepúsculos da Idade Média, o trespasse do rex imago Dei - que vigorou praticamente durante todo período medieval, cujo "fundamento ideológico último deve(ria) residir na passagem do politeísmo antigo ao monoteísmo" (LE GOFF, 2002, p. 396) e cujo desempenho real tangia, sobretudo, a uma trifuncionalidade (obedecer a Deus e servir à Igreja; assegurar a justiça e a paz ao seu povo; e prover suas necessidades) — para o rei absolutista deu-se subsidiado por uma primeira investida rumo a uma espécie de dessacralização do poder. Destarte, entre os séculos XII e XVI, a realeza passou a ser orientada por princípios racionais jurídicos: "Se tende a tornar-se absoluto, o rei deve submeter-se a essas duas grandes invenções do século XII, a razão e a natureza. O rei torna-se um 'senhor natural' e seu governo deve ser guiado pela razão. A realeza parece dessacralizar-se e passa-se de uma 'realeza centrada em Cristo' para "uma lei e uma humanidade centradas na realeza"'. (LE GOFF, 2002, p. 412)

Ademais, havia uma burguesia no meio do caminho: simultaneamente a essa quase subtração do caráter religioso do poder real, estabelecia-se a ascensão sócioeconômica burguesa, fazendo com que a lacuna existente até então entre ela e a nobreza (incluída nesta última, a própria realeza) se abrandasse. Tal aumento de poder e, consequente, aproximação da burguesia em relação à nobreza concorreram para uma passagem do conceito de courtoisie, que resumia a autoconsciência aristocrática e o 
comportamento socialmente aceitável da nobreza da cavalaria-feudalista, para aquele de civilité, do qual o "De civilitate morum puerilium", vindo a lume no século XVI (ano de 1530), de Erasmo, é sobremaneira representativo: "No decorrer do século XVI, o uso do conceito de courtoisie diminui lentamente na classe (aristocrática) enquanto o de civilité torna-se mais comum e, finalmente, assume preponderância" (ELIAS, 1994, p. 83). A "civilité" da nobreza pressupunha cuidados relacionados às boas maneiras quanto aos usos junto à mesa e à cama, ao esmero com a higienização, ao contato entre os sexos e à fala; no que tange a esse último aspecto, Norbert Elias cita o "Mots à la mode", de Callières, que, na edição de 1693, afirma: "Vocês sabem que o burguês fala de modo muito diferente de nós". Por meio da observação dessas normas de comportamento cotidiano, de etiqueta e boas maneiras, pretendia-se promover ou corroborar uma nítida distinção entre a elite aristocrática (inclusive a família real e, ainda mais, o próprio rei) e os demais estratos sociais mais ou menos alijados do poder político (principalmente a burguesia, estrato mais próximo da e, por isso mesmo, mais ameaçador à corte). Assim, o trabalho de Elias,

(...) vê na retenção, na continência e no governo de si bem mais que uma questão psicológica e sociológica: (trata-se antes de) uma questão fundamentalmente política, (de modo que) a ordem nas condutas aparece aí no fundamento do governo dos outros. O governo de si é aí um componente essencial do poder, o mais seguro entrave à desordem política, o complemento necessário à lei (HAROCHE, 1993, p. 53; grifos da autora; tradução nossa).

Nesse sentido, os tratados de civilidade instauram, traduzem, garantem e reforçam a existência e os limites de uma fronteira entre o homem exterior e interior, os homens de dentro e os homens de fora separados pelos fossos e muralhas dos castelos, mas ainda, pela língua, pelos gestos comportamentos e vestimentas - enfim, é uma fronteira física, mas também linguística, econômica, política e social.

A paulatina derrocada da nobreza e a crescente ascensão da burguesia podem ser observadas, de um modo complexificado, na passagem, assinalada por Foucault (1999 e 2000), do "poder soberano" para o "poder disciplinar", que comportava dois pólos, dois corpos: o individual, o corpo-máquina (dócil e produtivo), controlado por uma anátomopolítica; e o coletivo, o corpo-espécie (ser vivo e suporte de processos biológicos), controlado por uma biopolítica da população. Enquanto o primeiro, o soberano, baseava-se no "sangue", no nascimento e era caracterizado pelo "direito de vida e morte", ou seja, o "direito de causar a morte ou de deixar viver"; o último, o disciplinar, consiste num poder que gera e gere a vida dos corpos pessoal e social, um corpo diretamente mergulhado num campo político; sendo que seu aparentemente paradoxal surgimento, em meio à ascensão das Luzes, promoveu-se mediante a mobilização de instituições disciplinares como as escolas, as famílias, as fábricas, os hospitais, as prisões, que se instalam, sobretudo, a partir dos XVII e XVIII (FOUCAULT, 1999, 131): na sociedade disciplinar, "o indivíduo não cessa de passar de um espaço fechado a outro, cada um com suas leis: primeiro a família, depois a escola ('você não está mais na sua família'), depois a caserna ('você não está mais na escola'), depois a fábrica, de vez em quando o hospital, eventualmente a prisão, que é meio de confinamento por excelência” (DELEUZE, 2000, p. 219).

Essa época caracteriza-se, pois, pelas sofisticações das técnicas do poder que atuam sobre os corpos, de modo a "répartir dans l'espace, ordonner dans le temps, composer dans l'espace-temps" - repartir no tempo, ordenar no espaço, compor no espaço-tempo - (DELEUZE, 1986, p. 78), com vistas ao seu treinamento e à sua 
produção eficientes; nessa era, "viram-se aparecer técnicas de poder que eram essencialmente centradas no corpo, no corpo individual, por meio de procedimentos pelos quais se assegurava a distribuição espacial dos corpos individuais (sua separação, seu alinhamento, sua colocação em série e em vigilância) e organização, em torno desses corpos individuais, de todo um campo de visibilidade" (FOUCAULT, 2000, p. 288). Ademais, a Idade Clássica proporcionou, conforme já dito, essa intensificação sobre a normatização dos corpos, em razão da passagem do direito soberano para o poder disciplinar. Dado essa valorização da vida pelo poder disciplinar, quase nada que lhe concirna pode escapar-lhe ao alcance da minúcia de seu olhar potente, sendo, por extensão, a morte, em certa medida, o único reduto capaz de evadir-se do seu encalço, capaz de oferecer-lhe resistência: aqui, "o biológico reflete-se no político, fazendo com que haja uma proliferação de tecnologias políticas que, a partir de então, vão investir sobre o corpo, a saúde, as maneiras de se alimentar e de morar, as condições de vida, todo o espaço da existência" (FOUCAULT, 1999, p. 134-135). Daí decorre que a passagem do "sangue" e da "lei" (nobres ou aristocráticos) para o "corpo" e as "normas" (burgueses) não implicaram na ausência do controle, nem mesmo na sua atenuação, mas tão-somente num funcionamento de outra ordem, de outra natureza, mais sutil, menos agressivo, mas, possivelmente, mais eficaz: "enquanto pouco a pouco se vão desfazendo a ordem do nascimento e a hierarquia do sangue, no espaço da linguagem constroem-se práticas em que as relações entre os homens vão encontrar uma outra expressão, sem dúvida mais profunda e mais complexa." (COURTINE e HAROCHE, s.d., 21).

$\mathrm{O}$ ascendente predomínio dos valores burgueses, em detrimento dos aristocráticos, poderiam ainda ser observados tanto na descontinuidade da concepção de política instaurada a partir do século XVI - conforme o assinalou Foucault, em " $A$ Governamentalidade" (1985), ao apresentar as diferenças contidas nos tratados da arte de governar, que se estenderam do século XVI ao século XVIII, para com o imaginário de poder e governo encerrado no Princípe, de Maquiável - quanto nas transformações da expressividade da/na vida pública que se situa no século XVIII - segundo as indicações de Sennett (1988), de acordo com as quais a derrocada aristocrata, e o enfraquecimento de suas marcas visíveis, bem como o ascensão burguesa podem ser vistos no surgimento da figura do "estranho desconhecido", nas grandes cidades europeias, e no deslocamento da relevância do sobrenome e da tradição familiar nas relações da vida pública, entre os séculos XVII e XVIII: daquilo que primeiro deve ser apresentado, tornado público, no estabelecimento de uma conversação, para aquilo que deve ser preservado, deixado no íntimo da vida privada.

Com a ascensão simultânea e entrecruzada da "sociedade disciplinar" (FOUCAULT, 1999 e 2000) e do "paradigma da expressão" - "processo pelo qual (a partir do século XVI) a linguagem vai pouco a pouco passar a ser a medida de todas as coisas, dar sentido aos comportamentos, penetrar profundamente a interioridade subjetiva e fazer do corpo o lugar expressivo de uma voz íntima (COURTINE e HAROCHE, s.d., p. 27) -, ambos sintetizando e assinalando o crescente enfraquecimento dos valores aristocráticos, instaura-se concomitantemente mecanismos de controle da produção (aqui, o corpo produtivo) e da expressão, agora cumprindo funções determinantes no estabelecimento das relações sociais, (aqui, o corpo expressivo). Enquanto a "aristocracia tende a apreciar o espírito brilhante, mundano, polido, a graça, a ostentação, a exibição de si (....); a burguesia, no que lhe diz respeito, valoriza a virtude, a integridade, o esforço, a austeridade e as qualidades morais" (COURTINE e HAROCHE, s.d., p. 130), valoriza enfim os valores médios: a 
poupança, o domínio de si, a medida, a modéstia. Daí decorre o incessante controle sobre o corpo e sobre a língua: conforme a orientação de Vaumorière, em L art de plaire dans la conversation (1688), "A frase deve ser ornamentada com as flores da retórica, o corpo deve apresentar um porte gracioso e o rosto um ar aberto."; e tudo isso, sempre, sem excesso e com modéstia e medida precisas. Estabeleceram-se aí as condições de possibilidade para a emergência da Revolução Francesa. Essa revolução que deslocaria o "terceiro mundo" feudal de uma imaterialidade divino-transcendental para sua efetiva concretização no plano terrestre (não mais no tempo mítico, mas no tempo histórico), sob a forma do desmoronamento das fronteiras espaciais (o anacronismo do Palácio de Versalhes), da anulação das diferenças linguísticas (a instauração da Língua Nacional) e do fim das assimetrias corporais (o uso dos uniformes, segundo os preceitos revolucionários de Robespièrre): o otimismo de Hegel e a derrisão de Marx" ${ }^{1}$. Na Revolução Francesa era "preciso descobrir o que 'um cidadão' deveria ser. A igualdade formal vem junto com o surgimento do Estado Moderno e a consolidação de uma língua nacional, fazendo com que ocorresse "uma mudança estrutural na forma das lutas ideológicas: não mais o choque de dois mundos, separados pela barreira das línguas, mas um confronto estratégico em um só mundo, no terreno de uma só língua, tendencialmente Una e Indivisível, como a República" (PÊCHEUX, 1990, p. 11). Organizou-se uma unificação aparente, cujas subjacências apresentavam uma nova divisão social, com a cobertura da unidade formal do Direito herdeiro da política burguesa.

Se na revolução burguesa, a "'questão linguística' chega politicamente à ordem do dia", tendo em vista a unificação imaginária que passava necessariamente pela difusão e consolidação de uma língua nacional, é porque a burguesia viu-se diante da injunção de proclamar um ideal de igualdade frente à língua como condição para o estabelecimento da liberdade cidadã. Aparentemente, derrubaram-se as muralhas, taparam-se os fossos, abandonaram-se os castelos; contudo, a manutenção das desigualdades reais é assegurada, dentre outros modos, pelo desnivelamento, já antecipado e denunciado por Rousseau, estruturalmente reproduzido por uma divisão no ensino de língua e de gramática:

Esta divisão é política. O jogo de palavras burguês sobre o termo "liberdade" se mede pela distância que separa os projetos escolares revolucionários jacobinos (em particular, em matéria linguística, os de Condorcet), da realidade em 1880. Mas o deslizamento existe já no projeto jacobino: ao apresentar sintomaticamente como modelo a Gramática francesa de Lhomond, o ensino "completo" da língua francesa se constituía sobre o modelo do latim, reservando a experiência do bilinguismo à classe dominante, e fornecendo às massas uma gramática simplificada e truncada, baseada na lógica da frase simples. (PÊCHEUX, 1990, p. 21)

\footnotetext{
${ }^{1}$ Na mais famosa passagem de sua obra A fenomenologia do Espírito, Hegel concebe a Revolução Francesa como o fim da história humana, uma vez que a pretensão motivadora do processo histórico, ou seja, a luta pelo reconhecimento, encontra-se desde então realizada numa sociedade caracterizada pelo reconhecimento mútuo e universal: a elisão das contradições entre "senhor/escravo". Os princípios do cristianismo, da liberdade e da igualdade humana não mais se realizariam num plano divino-celestial, mas, dar-se-iam no aqui-agora mundano. Desse modo, não seriam mais necessários, nem sequer possíveis, os ajustes às instituições sociais. Não é, portanto, plausível nenhuma alteração histórica progressiva. A democracia liberal, que advém dessa revolução, substitui o insensato desejo de ser reconhecido como superior pelo prudente desejo de ser reconhecido como igual. Marx, por sua vez, via, mediante as lentes do materialismo histórico, a Revolução Francesa como "o acontecimento cristão por excelência", como o apagamento meramente formal das contradições e das lutas de classe de uma dada sociedade.
} 
Ao invés do término das assimetrias socioeconômicas e das lutas ideológicas, o que ocorre realmente é a instauração de "uma nova barreira, invisível, [que] não separa dois 'mundos'; ela atravessa a sociedade como uma linha móvel, sensível às relações de força, resistente e elástica, sendo que, de um e outro de seus lados, as mesmas palavras, expressões e enunciados de uma mesma língua, não têm o mesmo 'sentido'; esta estratégia da diferença sob a unidade formal culmina no discurso do Direito, que constitui assim a nova língua de madeira da época moderna, na medida em que ela representa, no interior da língua, a maneira política de negar a política" (PÊCHEUX, 1990, p. 11). Assim, se para os burgueses, na sua revolução, o objetivo era o de elidir as fronteiras manifestas presentes no mundo feudal-monárquico, para os revolucionários socialistas do século XIX europeu, os propósitos consistiam na denúncia das igualdades meramente formais da sociedade burguesa e na consequente politização do proletariado, de modo que esse último pudesse enxergar o "irrealizado", o "invisível" de sua época, e enxergar-se, tornando-se "visível para si mesmo", fazendo-se sujeito da história: "o mundo vai [ou, talvez, pudesse] mudar de base" (PÊCHEUX, 1990, p. 12).

No entanto, a "subversão da base do modo de produção capitalista, tal como a esperavam os revolucionários da época de Marx, não ocorreu; o que teve início com Outubro 17, e que constitui hoje 'o mundo socialista', se desenvolveu essencialmente na periferia do sistema capitalista” (PÊCHEUX, 1990, p. 13). É possível vislumbrar, na revolução socialista, alguns pontos afins entre sua política administrativa e linguística e aquela adotada pela revolução burguesa, quais sejam, a constituição de condições linguísticas necessárias ao exercício do novo poder do Estado, tendo em vista as complexas ramificações geográficas e culturais, a organização de uma superintendência adequada à administração do país, e de um exército apto a proteger sua independência; além dessas, a escolarização, a alfabetização e a difusão cultural da língua nacional integraram o programa político dos movimentos revolucionários socialistas.

Feitas algumas ressalvas, que sustentam a impossibilidade da idêntica repetição, dada a descontinuidade da história, há, tanto na Revolução Francesa quanto na Revolução Bolchevique, um fracasso no que concerne à promoção da igualdade efetiva: uma vez mais, talvez, surgisse a paradoxal tristeza-derrisória de Marx. O fato de que a revolução de 1917 tenha sido realizada no interior do mundo capitalista contribuiu decisivamente para a irrupção de novas fronteiras, posto que

o alhures realizado tomava a forma do "realizado alhures"': a impossibilidade de concretizar o "impensado", o sonho revolucionário em escala mundial. Desse modo, surge, por um lado, um limite exterior, que separa o interior do socialismo restrito e o exterior abrangente do universo capitalista, que tem a função de, simultaneamente, proteger contra a invasão e de prevenir e evitar as fugas, e, por outro, emergem fronteiras internas, cujo papel fundamental é a produção de efeitos hierarquizantes: "um certo retorno do sagrado feudal na ordem social: as hierarquias, as posições e os protocolos organizam a visibilidade do corpo glorioso da Revolução e asseguram a legitimidade do discurso oficial, tecido com referências aos textos fundadores e com fragmentos de memória coletiva, através dos quais o 'nós' do povo se dirige a si mesmo", de modo que "de um lado e de outro desta fronteira, a mesma palavra, a mesma frase não tem, de novo, o 'mesmo sentido'(PÊCHEUX, 1990, p. 14-15).

Novamente, o estabelecimento de um desnível entre a massa, de um lado, e a classe dirigente e a "intelligentsia" soviéticas, de outro, materializado no confronto 
entre variantes linguísticas, mas também, seguramente, na visibilidade do corpo político e no modus habitandis: esses últimos (dirigentes, porta-vozes e "intelligentsia"), de fato, não moravam, tal como a primeira (massa/classe operária), em casas populares.

\title{
2. Língua, corpo e movimento: controles urbanos e miditáticos
}

Se de Certeau diz que "chaque société a 'son' corps" - "cada sociedade tem seu corpo" -, Deleuze, por seu turno, afirma que a "cada tipo de sociedade, evidentemente, pode-se fazer corresponder um tipo de máquina" (2000, p. 216): máquinas de engrenagens, simples ou dinâmicas, máquinas a vapor e energéticas, máquinas cibernéticas e computadores estão respectiva ou, ao menos, preponderantemente para as sociedades de soberania, de disciplina e de controle.

\begin{abstract}
As antigas sociedades de soberania manejavam máquinas simples, alavancas, roldanas, relógios; mas as sociedades disciplinares recentes tinham por equipamento máquinas energéticas, com o perigo passivo da entropia e o perigo ativo da sabotagem; as sociedades de controle operam por máquinas de uma terceira espécie, máquinas de informática e computadores, cujo perigo passivo é a interferência, e, o ativo, a pirataria e a introdução de vírus. (DELEUZE, 2000, p. 223).
\end{abstract}

Também a língua, não a controlada, mas aquela que controla, mudou de aspecto, em nossos dias. O século XX e, a fortiori, o XXI têm, por isso, "sua"língua, "seus" corpos, "suas" máquinas, "sua" arquitetura. As formas do complexo de relações de força que hoje prevalecem tendem mais à abertura do controle contínuo e permanente que ao fechamento descontínuo das instituições disciplinares: "O que está sendo implantado, às cegas, são novos tipos de sanções, de educação, de tratamento. Os hospitais abertos, atendimentos a domicílio etc.” (DELEUZE, 2000, p. 216). No que diz respeito à educação, é possível facilmente observar que sua promoção é cada vez menos um conjunto de ações realizadas em um meio fechado, distinto do ambiente profissional; instaura-se a exigência da formação continuada tanto para o "operárioaluno" quanto para o "executivo-universitário", visto que numa sociedade de controle nunca se termina nada. Mais especificamente, a educação (-política) linguística parece ter aderido ao modelo pragmaticamente eficaz do "toda hora é hora/todo lugar é lugar de/para aprender", tendo como efeito reverso e perverso — de modo análogo ao que ocorre com a fórmula "Tudo é político", que se apresenta onde talvez quase nada mais o seja de fato — uma considerável deslegitimação do ensino formal e sério; possivelmente mais uma das facetas do encolhimento do (e do descrédito para com) o domínio político-público.

Ao se focalizar as práticas corporais, linguageiras e urbanísticas da sociedade contemporânea, surgem suas aparentes condições, posto que, aquém das reflexões sobre as relações de poder, o que se tem é abertura, sob a forma da libertação do corpo, e não mais seu disciplinamento, da liberação da fala, e não mais sua interdição, e da autonomia da ocupação e do movimento no espaço, e não mais sua restrição. Nesse sentido, a história caracterizaria a atualidade pela suposta inexistência de distinções, separações e segregações instauradas pelo poder, pela liberdade própria a uma época pós-vitoriana, desde o início do século XX, pós levantes feministas e de outras minorias, pós Maio de 68, desde a segunda metade desse século, e, especialmente no Brasil, pós abertura política, que se seguiu à derrocada da Ditadura Militar, a partir do final dos anos 70: direito à livre expressão, direito ao próprio corpo. Ocorre que não se trata, de fato, da efetivação do ideário democrático e igualitarista, mas, antes, de uma passagem, 
de um deslizamento, visto que se pode vislumbrar na atuação do poder (pós-)moderno um largo deslocamento que vai do "controle-repressão", próprio da sociedade disciplinar, para aquele do "controle-estimulação", das sociedades de controle, no qual se observa a eficiência da fórmula "Fique nu ... mas seja magro, bonito, bronzeado!" (FOUCAULT, 1985, 147); esta fórmula poderia ser, sem maiores problemas, arrastada para o âmbito linguístico, na medida em que se sucedem as injunções ao dizer, à fruição dos direitos da liberdade de expressão, e se manifestar na forma do seguinte imperativo: "Todos podem/devem falar... mas não de qualquer jeito!" (sob a pena de não serem ouvidos, ou de terem suas falas circunscritas, sem a promoção de maiores ecos, ou estigmatizadas). Fato que não implica a atenuação efetiva das coerções e da inspeção das condutas. Talvez, fosse mais acertado salientar, inclusive, um certo e considerável reforço dos controles, tendo em vista, por exemplo, que

o momento narcísico da cultura do corpo nos Estados Unidos corresponde, não a um laisser-aller hedonista, mas a um reforço disciplinar, a uma intensificação dos controles. Ele não corresponde a uma dispersão da herança puritana, mas antes a uma repuritanização dos comportamentos, cujos signos, de modo mais ou menos explícito, multiplicam-se hoje. (COURTINE, 1995, p. 105).

É preciso sublinhar que, no que se refere à estimulação à aparição midiática do corpo nu ou quase desnudo, não se trata, com efeito, de uma inversão dos ou de uma ruptura com os paradigmas clássico-platônico e judaico-cristão, segundo os quais na dicotomia "Corpo/Alma", valoriza-se demasiadamente a segunda em detrimento do primeiro. Antes, trata-se de uma certa permanência histórica da valorização do plano ideal, visto que, de modo análogo ao que ocorre na cultura do body-building dos Estados Unidos, na qual os músculos, num puritanismo ostentatório, escondem o sexo, conforme o postulou Courtine (1995), as asperezas repulsivas da carne real são obliteradas frente à onipresença midiática, seja nos vídeos seja nas páginas, dos corpos de luz e de papel.

O fechamento, a saturação e a cisão "dentro/fora", dos quais fala Pedro de Souza (s.d.) $)^{2}$, coadunam-se quase que indefectivelmente com as políticas do corpo e da língua da sociedade brasileira atual, visto ser ele mais um dos meios constituídos com vistas à segregação e ao alijamento daqueles que não atendem a um e não se enquadram num padrão normalizante/normatizante. Por absorver em boa medida um conjunto de representações acerca do que seja "a" língua portuguesa, ou o seu bom uso, do que seja "o" corpo, ou a sua forma esteticamente viável, uma considerável parcela dos sujeitos de nossa sociedade veem nas especificidades de seus corpos, a feiura, e nas particularidades de sua variante linguística, a incorreção, inscrevendo-se numa exterioridade, num "do lado de fora", de modo semelhante ao que acontece com a inacessibilidade e com exclusão promovidas por meio das grades, da altura dos muros, das cercas elétricas, e, sobretudo, dos condomínios fechados, que sintetizam os casos mais emblemáticos do distanciamento, da "clausura" voluntária, da segregação, do nãoacesso ou, mais radicalmente, da impossibilidade de habitar, da frustração do desejo de ter um "canto". É justa e paradoxalmente o canto da "Saudosa Maloca", de Adoniran

\footnotetext{
2 “As grades são parte de uma ordem simbólica que promove o barramento da circulação e sob efeito transverso de discursos sociais. Deste modo, instaura posições de discurso nas quais os indivíduos podem, de um certo modo, referir-se a si como cidadãos. Ocorre que os passantes na rua, a cada vez que se deparam com uma grade ou um portão interrompendo a passagem ou a entrada em um parque, do ponto de vista do direito à cidade, são constituídos em sujeitos na exterioridade, ou seja, são levados a identificar-se como os que ficam do lado de fora" (SOUZA, s.d., p. 11).
} 
Barbosa, uma das sínteses da incidência multifocal do poder; a constituição de um sujeito excluído da/pela língua e do/pelo espaço, quase sem voz, ainda com um canto; quase sem pedra, ainda com um jardim:

Se o sinhô não tá lembrado/ Dá licença de cantá,/ Que aqui onde agora tá/ Esse edifício arto/ Era uma casa véia,/ Um palacête assobradado./ Foi aqui seu moço/ Qu'eu, Mato Grosso e o Joca/ Construímo nossa maloca./ Mais um dia,/ Nóis nem pode se alembrá,/ Veio os home com as ferramenta,/ O dono mandô derruba./ Peguemo todas nossas coisa/ E fumos pro meio da rua/ Preciá a demolição./ Que tristeza que nóis sentia,/ Cada tábua que caía/ Duia no coração./ Mato grosso quis gritá/ Mais em cima eu falei:/ Os home tá co`a razão,/ Nóis arranjá outro lugá./ Só se conformemo quando o Jocá falou:/ Deus dá o frio conforme o cobertô,/ E hoje nóis peça a paía nas gramas do jardim/ E pra esquecê nóis cantemos assim:/ Saudosa Maloca, maloca querida, dim dim/ Donde nóis passemo os dias feliz da nossa vida./ Saudosa Maloca, maloca querida, dim dim/ Donde nóis passemo os dia feliz da nossa vida.

A canção de Adoniran Barbosa permanece "do lado de fora" ao ser apresentada como alegoria do "mau falar" em contextos de reflexão linguística, especialmente naqueles avaliativos de conhecimento na norma culta da língua. Joca, Mato Grosso e todos os que tiveram sua saudosa maloca destruída "pelos home" foram obrigados a buscar um outro espaço, sem dúvida ainda mais periférico, mas que lhes garantia a existência. $\mathrm{O}$ gênero canção popular, mais especificamente o samba, é um dos poucos espaços em que a língua coloquial pode ser legitimamente registrada dentro dos muros da educação formal, assim como as pichações nos muros dos condomínios fechados são um dos poucos espaços em que os excluídos, como são Joca e Mato Grosso, podem ser ouvidos. Tão logo ouvidos, são apagados: seja por meio de exercícios de correção gramatical da canção popular nas aulas de língua portuguesa, seja pela tinta apagando a voz dos muros, no dia seguinte. Mesmo salvaguardada pelo gênero canção, "Saudosa maloca" não escapa, ainda, de ocupar o espaço de "bestiário inculto" na instituição maior que seria a Língua Portuguesa e, ato contínuo, a cultura: ou seja, seu discurso, ao ser fagocitado pela cultura oficial, necessita ser colocado entre as chaves da "concessão" linguística: antes como devir de linguagem que linguagem. O motivo não é outro, senão um espelhamento da segregação do próprio espaço urbano, tão imbricado com a própria linguagem na canção de Adoniran Barbosa. Restaria ainda sublinhar que esses mesmos recursos linguísticos em canções que pertencem a um cânone elitizado (legitimado pela cultura, portanto), como as de Chico Buarque, seriam lidos como recursos de parataxe ou deslocamentos semânticos: em "Saudosa maloca" tal leitura é impossível, pois parte de uma desvalorização do falante que lhe retira o poder sobre sua linguagem e, consequentemente, sua construção poética.

A produção e a cristalização dessas representações do corpo e da língua têm se tornado cada vez mais intensas e eficientes, graças à força da mídia, que, pelo fato de consistir atualmente numa das mais fundamentais instâncias de constituição de representações imaginárias, objetiva e naturaliza o mundo, constrói e propaga uma série de "verdades". Coextensivas do encolhimento/enfraquecimento da política e da pedagogia strictu sensu, dão-se a politização ${ }^{3}$ e a pedagogização da mídia: uma vez que a sociedade do controle se caracteriza pela abertura e continuidade das instituições,

\footnotetext{
${ }^{3}$ Ver PIOVEZANI, C. Política midiatizada e mídia politizada: fronteiras mitigadas na pós-modernidade. In: GREGOLIN, M. R. V. Discurso e mídia: a cultura do espetáculo. São Carlos/SP: Claraluz, 2003.
} 
observa-se o aumento da atuação midiática que, para além da transmissão de informações e do entretenimento, pretende supostamente exercer papéis políticos e pedagógicos. E se a "formação permanente tende a substituir a escola, e o controle contínuo substitui o exame" (DELEUZE, 2000, p. 221), a mídia brasileira tem aspirado a preencher os vazios deixados pela derrocada do ensino tradicional; em suma, a esfera midiática cumpre (ou pretende cumprir) a função da escola sem, entretanto, abdicar de procedimentos congêneres daqueles utilizados pelos aparelhos escolares. Daí decorre o fato de a mídia brasileira, com efeito, estar desenvolvendo um trabalho de controle sobre as práticas linguageiras e corporais, por meio das quais os indivíduos tornam-se sujeitos, erigindo balizas rígidas (o corpo malhado e a manifestação linguística na norma-padrão do português) no interior de instâncias suficientemente reguladas e necessariamente maleáveis (estruturas passíveis de jogo). Não se trata, contudo, no que tange especificamente à língua, de assim proceder, objetivando "homogeneizar 'o' português brasileiro", pondo em risco nossa diversidade linguística (a existência e a manutenção da variedade são condições de possibilidade para a eleição e a consagração de apenas uma das variantes: amiúde, aquela mais interessante sócio-economicamente); o que ocorre, de fato, é a criação de uma necessidade, é a veiculação de uma publicidade e, ainda, a construção de uma série de práticas exclusivistas e separatistas ${ }^{4}$ de subjetivação.

Cabe, ainda, não desconsiderar um outro aspecto bastante presente nos procedimentos midiáticos, qual seja, aquele de acordo com o qual os discursos que constroem representações sobre os corpos e sobre a língua não provêm somente das esferas e dos sujeitos especializados; aí, em detrimento, em alguma medida, da competência do especialista, institui-se o que de Certeau designa por "abuso de saber". É assim que se dá o movimento que permite o pronunciamento/controle das condutas corporal (dietética) e linguística (gramatiqueira) dos peritos que "intervêm 'em nome' - mas fora - de sua experiência particular" (DE CERTEAU, 2000, p. 66), mediante a conversão da competência em autoridade: "No limite, quanto maior a autoridade do perito, menor a sua competência" (DE CERTEAU, 2000, p. 66). Não sem razão, irrompem na mídia os múltiplos "conselhos", as "valiosas" indicações, as "inestimáveis" sugestões que concernem principalmente ao corpo, mas, também, à língua: as dicas de beleza e saúde do Bem Estar e a dieta da Sabrina Sato; os alvitres gramatiqueiros do Pedro Bial aos participantes do Big Brother Brasil e as deliberações "linguísticas" do Serginho Groisman, seja no Altas Horas, no Ação ou no Alô Brasil! Aqui tem educação. Certamente, os especialistas (os médicos e os fisiologistas, para o corpo, com considerável frequência, os gramáticos, esporadicamente, e os linguistas, quase nunca) não estão ausentes; eles são interpelados com vistas a ratificar as dicas já dadas, a emitir suas opiniões e a apresentar as novidades sobre beleza e saúde; entretanto, a ressonância dos comentários dos "peritos", cuja iniciação à ordem midiática foi bem sucedida ${ }^{5}$ e cuja competência abrangente (quase ilimitada) advém de

\footnotetext{
${ }^{4}$ Talvez, essa excessiva regulamentação lingüística, essa quase obsessão gramatiqueira, remonte a um dos sonhos dos primórdios adâmicos, tempo mítico no qual existia a "língua perfeita"; antes da danação da confusio linguarum, segundo a primorosa incursão de Umberto Eco, em "A busca da língua perfeita" (2002); ou se deva ao desejo, correlato da comunicação indefectível, que é aquele de tudo ver/saber, a omnisciência, de acordo com a afirmação de Courtine: "La transparence de la langue redouble le plan géométrique des villes utopiques, le nivellement d'un paysage dont on a parfois effacé les montagnes, l'harmonie qui règne entre les sexes et les classes. Nul accroc au regard... Triomphe de la géométrie dans la langue, mais surtout, triomphe du regard sur la langue". (COURTINE, 1984, p. 209).

5 "Não podendo ater-se ao que sabe, o perito se pronuncia em nome do lugar que sua especialidade lhe valeu. Assim ele se inscreve e é inscrito numa ordem comum onde a especialização tem valor de iniciação enquanto regra e prática hierarquizante da economia produtivista. Por se ter submetido com êxito a esta prática iniciática, ele pode, sobre questões estranhas à sua competência técnica, mas não ao poder que por ela se adquire, proferir
} 
sua celebridade, de sua circulação entre os ricos, chiques e famosos, é inquestionavelmente mais difusa e abundante. Como se o fato de ser célebre e prestigiado, numa dimensão alheia à produção científica, e/ou de gozar de uma forma física privilegiada (sendo que essa última condição, por vezes, é garantia para a aquisição da primeira), segundo os modelos midiáticos contemporâneos, assegurasse o saber, a legitimidade e a autoridade dos juízos tecidos acerca dos usos do corpo e da língua. Ademais esses pretensos saberes, legitimidades e autoridades não são pesados nem carrancudos, antes têm a leveza de uma região de dizer aparentemente folgazã e despretensiosa, na qual, de fato, impõe-se uma ordem do discurso rígida e amplamente controlada, ainda que sob a forma das leves e homeopáticas doses de sugestões sobre a boa forma e o bem falar. Uma vez mais a política (aí, singela e delicada, mas contundentemente sentida e eficaz) no corpo e na língua.

Caberia, ainda, uma reflexão acerca do simulacro de cultura empreendido por essas instâncias e instituições da cultura massificada. Nossa era prefere "a imagem à coisa, a cópia ao original, a representação à realidade, a aparência ao ser" (Feuerbach apud Debord, 2011, p.13), o que valeria dizer que a indústria cultural, ou espetáculo, nos termos como a compreendeu Guy Debord, ao demonstrar-se como "uma enorme positividade, indiscutível, inacessível", nada diz além de "o que aparece é bom, o que é bom aparece." Este "monólogo da aparência" guarda em si a estrutura de fragmentação do homem em meio a uma cultura "invertida", onde "a unidade dessa mesma vida já não pode ser reestabelecida" (p.13-17). Fragmentado, pois, de uma unidade com a cultura, o homem perde, entre todas as "posses" necessárias à vida, certamente aquela que é a mais forte: a relação com a linguagem e a da linguagem como instrumento de decifração do maquinário que essa indústria tece em torno do sujeito, tolhendo-lhe qualquer liberdade ou identidade frente a uma cultura onde o simulacro apresenta-se como projeto de controle biopolítico onipresente: apresenta-se como real, quando "no mundo realmente invertido, o momento do real é o momento do que é falso" (idem, p.16).

Especificamente, no tocante à língua, e, de modo ainda mais preciso, aos prelúdios históricos dos discursos e práticas que controlam ou, ao menos, intentam controlar seus usos, a presença da política é evidente, sobretudo no que diz respeito à relação basilar entre a instituição de uma língua oficial e os fundamentos da unificação de um estado nacional. Diante de uma possível correspondência entre as realidades francesa [motivada por uma das prestimosas indicações do texto de Pêcheux (1990)] e brasileira, poder-se-ia sustentar que a instituição das línguas nacionais subsidiou-se mais em decisões eminentemente políticas que em arbítrios propriamente linguísticos; e isso tanto na França como no Brasil. Todavia, enquanto lá, em função do fato de que a "impossibilidade de um compromisso com a monarquia empurrou a burguesia para uma aliança popular" (PÊCHEUX, 1990, p. 11), bem como pela própria razão de essa mesma burguesia falar francês, os falares vulgares, a língua francesa largamente utilizada, foram contemplados, malgrado a instauração da "langue de bois" do Direito e da Política burguesas; no Brasil, o estabelecimento da língua portuguesa como Língua Nacional oficial, com o decreto de Pombal, no ano de 1759, em detrimento da Língua Geral, amplamente usada aqui naqueles tempos, e de várias línguas indígenas, essas últimas com a desvantagem, conforme a concepção das culturas letradas, de serem ágrafas, produziu o surgimento de um modelo, baseado na norma-padrão do português europeu, para toda produção linguística engendrada em terras brasileiras. 
Possivelmente, tenha derivado daí a série de discursos que, insistentemente e para além dos espaços de ensino tradicionais e supostamente competentes, como é o caso das atuais restrições e dicas midiáticas sobre a língua portuguesa, sentenciam normativa e valorativamente as práticas linguageiras. E, ao pensar a relação da língua, com o corpo e com o espaço urbano, poder-se-ia aventar que, se o controle da primeira vem pela norma-padrão, o do segundo, vem pelo padrão estético dominante, e o do terceiro, vem, dentre outros modos, pelas barragens e fronteiras da cidade; três formas de controle eficientes, porém não absolutamente hegemônicas: há, ainda, um "real da língua" (Milner), um "real do corpo" e um "real da cidade", visto que o "real" é o impossível (de se dar e de se abranger na totalidade: talvez, um pouco/um muito de Nietzsche e Saussure em Lacan), ou, antes, a possibilidade e a propriedade intrínseca do "um" de "tornar-se outro, diferente de si mesmo, se deslocar discursivamente de seu sentido para derivar para um outro"; enfim, toda manifestação linguística, corporal ou citadina está/é crivada por uma série de "pontos de deriva possíveis" (PÊCHEUX, 1997, p. 53), ainda que haja os cerceamentos dado pelas regularidades da língua, pela naturalização do corpo e pela elisão do espaço.

Os impasses e os atrasos do Brasil devem-se em ampla medida à força das ideologias e discursos conservadores e reacionários que, gestados por sua elite e nutridos por ela mesma e por boa parte das classes médias, disseminam-se contraditoriamente entre aqueles que são seus principais alvos e os mais prejudicados por tal disseminação. Qualquer programa social progressista que se anuncie ou se implemente é posto imediatamente na mira dessas ideologias e discursos e fartamente alvejado por eles. Porque se trata de instrumento e foco privilegiados de resistência e desconstrução que lhes poderiam ser feitas, o mesmo ocorre com os ditos e as maneiras de dizer oriundos dos meios populares, que são pronta e profundamente infamados. Assim, a oratória e a eloquência que carregam as marcas do povo pobre brasileiro são intensa e extensamente tachadas de incorreção, de deselegância, de vulgaridade e, quando não, de barbárie. Em que pese sua onipresença, há contextos em que sua ocorrência torna-se ainda mais patente e agressiva, tal como aconteceu quando da repercussão do anúncio do câncer de laringe de Lula, em outubro de 2011, e da divulgação de sua cura, no final de março de 2012. Numa paráfrase da paráfrase que Millôr Fernandes fez da famosa frase de Samuel Johnson, poderíamos dizer o seguinte: $\mathrm{O}$ preconceito linguístico é um último refúgio dos canalhas. No Brasil, frequentemente é também o primeiro. Eis abaixo as palavras de uma jornalista de outro grande veículo de nossa mídia tradicional:

O presidente que cometeu mais gafes na história do Brasil conseguia quase sempre roubar a cena ao abrir a boca. (...) Sua voz rouca, com erros de português, metáforas de futebol e piadas do povão, era o elo com a massa, na versão sindicalista exaltado ou do lulinha paz e amor. O Brasil teve outros oradores inflamados (...) que se expressavam com vigor também na escrita. Lula não. Exerce uma liderança oral. A maioria da população brasileira não domina a palavra escrita. (...) Num país assim, a voz é hipervalorizada como capital simbólico. Lula sempre falou demais. (Ruth de Aquino. "A voz de Lula". Revista Época.)

A capacidade comunicativa do ex-presidente é subsumida numa série de supostas impropriedades, que a questionam e denigrem. Apesar de conseguir "roubar a cena ao abrir a boca", de estabelecer um "elo com a massa" e de exercer uma liderança, Lula somente os teria feito na modalidade oral e, conforme a acusação preconceituosa 
da jornalista, cometendo gafes como nenhum outro presidente jamais o fizera, "com erros de português, metáforas de futebol e piadas do povão" e sempre falando demais. Os dois estilos do orador, "sindicalista exaltado" e "lulinha paz e amor", correspondem às "duas caras" do sujeito, cujo público, que o legitima com seu apoio, é também deslegitimado e descreditado: a "massa", a "maioria da população brasileira", que lhe dera tanta popularidade, fizera-o, segundo a tendenciosa opinião da jornalista, porque pretensamente não domina a elegância e a precisão da "razão gráfica" e deixa-se ludibriar pela manipulação retórico-vocal do ex-presidente.

\section{O fim e o começo, o dentro e o fora: ações e reações, controles e resistências}

É com base em duas máximas frequentemente reiteradas nas mais diversas disciplinas situadas no interior do macro-campo das ciências humanas, quais sejam, " $\mathrm{Le}$ corps est le premier et le plus naturel instrument de l'homme" - "O corpo é o primeiro e o mais natural instrumento do homem" - (de Marcel Mauss, em 1934) e "É na e pela linguagem que o homem se constitui como sujeito" (de Émile Benveniste, em 1958), que começamos a traçar o fim (provisório) das reflexões por nós aqui delineadas. Tomamo-as por subsídio pelo fato de que elas sinalizam para o investimento do corpo ("o primeiro e o mais natural instrumento do homem") e da língua (o sistema semiótico, por excelência, no vasto campo da linguagem) na constituição histórica da própria "humanidade" do homem, de sua subjetividade e de sua cidadania. Acreditamos que se possa afirmar, a partir das considerações de Mauss e de Benveniste, atravessadas pelo viés histórico-discursivo, que o corpo e a língua são materialidades simbólicas, sobredeterminadas por demandas imaginárias, por meio das quais são processados modos de subjetivação próprios da configuração específica de uma sociedade na história, de modo que a subjetividade se construa/seja construída com e no corpo, com e na linguagem; mas, também, com e no espaço (nunca vazio de sentidos) da cidade. Tendo em vista a necessidade (não apriorística, baseada num idealismo transcendental, mas, histórica, contraditória e descontínua) de uma língua, de um corpo e de um espaço para a constituição da subjetividade, é que, orientado pelas referências sobre as quais nos apoiamos, concebemos a possibilidade de traçar alguns esboços rudimentares que apontam para os controles que perpassam a língua, o corpo e a cidade: liames entre dizer(-se), mostrar(-se) e construir(-se).

Pretendíamos, por meio de sumária incursão histórica, que sublinha a ubiquidade midiática de nossa sociedade de controle, levantar algumas hipóteses de trabalho e considerar alguns procedimentos mediante os quais são engendrados, tanto pelas representações da mídia quanto pela organização do espaço urbano, modelos de conduta para o comportamento linguageiro, para a apresentação corporal e para a ocupação citadina/o movimento cidadão. O sujeito (pós)moderno constitui-se, por um lado, no jogo midiático entre a visibilidade radiante/impetuosa da beleza e a dissimulação constrangida/recalcada da feiura, entre a correção eloquente/exuberante do "bem falar" e a imperfeição emudecedora/intimidante do "falar errado"; e, por outro, na cisão urbana do "dentro" (da proteção, da segurança, da inclusão/deferência) e do "fora" (da ameaça, do risco, da exceção/elisão). Cabe, contudo, salientar que o fechamento dos condomínios, dos muros, das grades, a inclusão no "dentro" não corresponde à renúncia da ostentação (o carro, as joias, as roupas etc., mesmo que, por vezes, ocultados com o intuito de assegurar a proteção fora dos muros, são ainda ícones bastante presentes, desempenhando a função distintiva). Aliás, o mostrar-se é uma das condições da/para a existência (pós-)moderna; quer-se mostrar os índices da prosperidade, a eloquência, a 
boa forma; quer-se mostrar até mesmo o que antes ficava escondido, mas que agora passou a ser um símbolo de fortuna e de pertença ao clube dos belos e saudáveis:

(...) ‘jovens profissionais urbanos’, ávidos pela autorrealização através do sucesso material, praticantes mais assíduos da transpiração eletrônica, fizeram desse tipo de aparelhagem um signo essencial de pertencimento a seu grupo: as máquinas de remar, pedalar, simular a subida dos degraus da escada, passaram a ser um elemento de decoração doméstica, uma peça do mobiliário colocado à vista, enquanto que, no passado, os halteres descansavam discretamente no fundo de um armário. (COURTINE, 1995, p. 85)

É, nesse sentido, que cremos haver, no tempo presente, uma certa correspondência ${ }^{6}$ entre o alijamento do corpo "feio", do dizer "cacofônico" e o contato/conflito urbano, tornado violência, por meio do engendramento dos muros, das grades e dos condomínios fechados; contudo, a correspondência aqui vislumbrada pode parecer simples demais para dar conta da generalidade do fenômeno, fácil demais para exprimir sua complexidade. Por isso, frente ao surgimento dos fenômenos contemporâneos, parece-nos necessário considerar sua dimensão histórica e sua natureza compósita, constituídas tanto por permanências parciais quanto por irrupções singulares, de modo a não conceber os acontecimentos como rupturas permanentemente inéditas, nem neles vislumbrar a continuidade inabalada da história, numa filia pela repetição e pela teleologia.

Pode-se, então, contemplar a especificidade dos atuais enlaces entre o corpo e a língua, no interior tanto das da ubiquidade midiática, articulados com as injunções empreendidas pelo espaço (absolutamente, projetado/preenchido) urbano na constituição dos sentidos e dos sujeitos da cidade, presentificados na constância de suas ações sobre o conjunto de ações possíveis dos sujeitos e dos sentidos em constituição. Todavia, não se deve desconsiderar os fundamentos históricos dessa emergência, a memória dessa atualidade; visto que, novamente parafraseando de Certeau, cada sociedade tem seu corpo, sua língua e seu espaço, é possível avançar dizendo que, no mínimo, desde a Antiguidade Clássica já havia uma certa conivência entre essas três dimensões, uma certa "episteme" e um certo "diagrama" (ambos, no sentido foucaultiano) que organizaria essas três ordens: na Grécia Antiga, o cidadão grego orientava-se pelo e para o "sophrosyne", ideal de prudência e moderação do corpo, mas também da língua, expunha seu corpo e seus templos, enquanto o bárbaro, era aquele que não falava grego e que cobria seu corpo com peles. Em Roma, a distinção entre arx, urbs e burgo, que, respectiva e aproximadamente, estão para o castelo (no cimo da cidade), a cidade e o subúrbio; os dogmas de Adriano, de Cícero e de Sêneca ("Meocritas optima est." e "Omnis in modo est virtus.") incidiam sobre as práticas corporais e linguageiras; e Vitrúvio estabeleceu a planta de suas construções com base no modelo do homem romano. Na França, durante a Idade Média, os muros, fossos e castelos, o corpo sumptuoso da nobreza e o latim separam e segregam; e, ainda, na França, mas a do século XVI, as boas maneiras, que abrangiam desde os modos de portar-se à mesa até aqueles do "bem falar", da sociedade dos costumes, da "civilitê". Na sociedade das disciplinas e do paradigma da expressão, entre os séculos XVI e XIX,

\footnotetext{
${ }^{6}$ Aqui, penso (conservando e subvertendo) a "relação de homologia", de Benveniste (1989), e, de uma certa maneira, articulo-a com o "diagrama", de Foucault (1987), cuja reconfiguração/ampliação é devida a Deleuze: "Le 'diagramme', ce n'est plus l'archive, auditive ou visuelle, c'est la carte, la cartographie, coextensive à tout le champ social. C'est une machine abstraite. (...) C'est une machine presque muette et aveugle, bien que ce soit elle qui fasse voir, et qui fasse parler.” (DELEUZE, 1986, p. 42)
} 
a intensificação dos controles da produtividade e da expressividade, até as regras de conduta hi-techs (cibernéticas, informáticas, digitais, televisivas etc.) dos nossos dias.

Com vistas a finalizar nossas considerações, propomos, sempre numa perspectiva histórica, que, diante dos exercícios de $\operatorname{poder}^{7}$ da sociedade de controle, seja no que concerne à língua, ao corpo ou à cidade, nos orientemos pelo princípio da diferença ${ }^{8}$ e pelo postulado da liberdade, ambos foucaultianos, de acordo com os quais as maiores e mais difíceis lutas do tempo presente são aquelas que consistem na permanente inquietação filosófica de saber "Quem somos nós?", empreendida pioneiramente por $\mathrm{Kant}^{9}$; ou, antes, na recusa do que somos, do que nos fizeram ser ou do que querem que sejamos: "Talvez, o mais evidente dos problemas filosóficos seja a questão do tempo presente e daquilo que somos neste exato momento. Talvez, o objetivo hoje em dia não seja descobrir o que somos, mas recusar o que somos. Temos que imaginar e construir o que poderíamos ser..." (FOUCAULT, 1995, p. 239).

\section{Referências}

AQUINO. Ruth de. "A voz de Lula". Revista Época. 30 de março de 2012. Disponível em: http://revistaepoca.globo.com/Mente-aberta/ruth-de-aquino/noticia/2012/03/voz-de-lula.html

ARISTÓTELES, Política. In: Aristóteles. São Paulo: Nova Cultural, 1999. (Coleção Pensadores) (p. 141-251)

BENVENISTE, Emile. Problemas de lingüística geral II. Campinas: Pontes, 1989.

BENVENISTE, Emile. Problemas de lingǘstica geral I. 4. ed. Campinas: Pontes, 1995.

BOURDIEU, Pierre. Sobre a televisão. Rio de Janeiro: Jorge Zahar, 1997.

COURTINE, Jean-Jacques. La meilleure des langues. In: Lingüistique fantastiquè. Paris: Denoël, 1984.

Os stakanovistas do Narcisismo: Body-building e puritanismo ostentatório na cultura americana do corpo. In: SANT’ANNA, D. B. (Org.) Políticas do corpo. São Paulo: Estação Liberdade, 1995. (p. 81-114)

DE CERTEAU, Michel. Histoires de corps. In: Esprit, Paris, nº 2, 1982. (p. 179-185)

A invenção do cotidiano: artes de fazer. Petrópolis: Vozes, 2000.

\footnotetext{
${ }^{7}$ A própria concepção foucaultiana acerca do poder e da natureza de seu exercício pressupõe e assente a resistência ativa, o trabalho da rebeldia e da liberdade: "O exercício do poder (...) é um conjunto de ações sobre ações possíveis; ele opera sobre o campo de possibilidade onde se inscreve o comportamento dos sujeitos ativos; ele incita, induz, desvia, facilita ou torna mais difícil, amplia ou limita, torna mais ou menos provável; no limite, ele coage ou impede absolutamente, mas é sempre uma maneira de agir sobre um ou vários sujeitos ativos, e o quanto eles agem ou são suscetíveis de agir. Uma ação sobre ações. (...) Quando definimos o exercício do poder como um modo de ação sobre as ações dos outros, quando as caracterizamos pelo 'governo' dos homens, uns pelos outros — no sentido mais extenso da palavra, incluímos um elemento importante: a liberdade. O poder só se exerce sobre "sujeitos livres", enquanto "livres" - entendo-se por isso sujeitos individuais ou coletivos que têm diante de si um campo de possibilidade onde diversas condutas, diversas reações e diversos modos de comportamento podem acontecer." (FOUCAULT, 1995, p. 243-244)

${ }^{8}$ Ressalto que esse princípio, segundo o qual "a diferença, longe de ser origem esquecida e recoberta, é a dispersão que somos e que fazemos." (FOUCAULT, 1997, p. 151), estabelece uma série de convergências com as noções de "pontos de deriva" e de "resistência" em Pêcheux (ver Delimitações, Inversões, Deslocamentos, p. 17): em suma, a presença do e o direito ao "outro" sentido/sujeito na língua, no corpo e na cidade, tal como já postulava Aristóteles quando dizia que "uma cidade é construída por diferentes tipos de homens; pessoas iguais não podem fazê-la existir", ou, ainda, que "o Estado é uma associação de homens livres." (1999, p. 223)

9 Diante da inquietação kantiana - "Se for feita então a pergunta: 'vivemos agora em uma época esclarecida'?, a resposta será: "vivemos em uma época de esclarecimento"” (KANT, 1985, p. 112)—, problematiza-se o presente; ou conforme assevera Foucault: "A questão que me parece surgir pela primeira vez no texto de Kant, é a questão do presente, da atualidade: que é que se passa hoje? Que é que se passa agora? E o que é este 'agora' no interior do qual estamos uns e outros." (FOUCAULT, 1984, p. 103)
} 
DEBORD, Guy. A sociedade do espetáculo. Rio de Janeiro: Contraponto, 2011.

DELEUZE, Gilles. Foucault. Paris: Éditions de Minuit, 1986.

Conversações. Rio de Janeiro: Editora 34, 2000.

ECO. Umberto. A busca da língua perfeita. 2. ed. Bauru: Edusc, 2002.

ELIAS, N. O processo civilizador: uma história dos costumes (vol. 1). Rio de Janeiro: Jorge Zahar Editor, 1994.

FOUCAULT, Michel. O que é o iluminismo? In: ESCOBAR, C. H. Michel Foucault - o dossiê: últimas entrevistas. Rio de Janeiro: Taurus Editora, 1984. (p. 103-112)

. Microfísica do poder. 5. ed. Rio de Janeiro: Graal, 1985

Vigiar e punir. Petrópolis/RJ: Vozes, 1987.

. O sujeito e o poder. In: RABINOW, P. e DREYFUS, H. Michel Foucault: uma trajetória filosófica. Rio de Janeiro: Forense Universitária, 1995. (p. 231-249)

. Arqueologia do Saber. 5. ed. Rio de Janeiro: Forense Universitária, 1997.

1999.

História da sexualidade I: a vontade de saber. 3. ed. Rio de Janeiro: Graal,

Em defesa da sociedade. São Paulo: Martins Fontes, 2000.

GADET, Françoise. e PÊCHEUX, Michel. La langue introuvable. Paris: Maspero, 1981.

HAROCHE, Claudine. Se gouverner, gouverner les autres: Élémentes d'une anthropologie politique des moeurs et des manières (XVIe-XVIIe siècle). In: Communications 56: Le gouvernement du corps. Paris: Seuil, 1993. (p. 51-68)

KANT, Immanuel. Que é "Esclarecimento"? In: Immanuel Kant: Textos Seletos. Petrópolis: Vozes, 1985. (p. 100-117)

KANTOROWICZ, Ernst. Os dois corpos do rei : um estudo sobre teologia política medieval. Trad. Cid Knipel Moreira. São Paulo : Companhia das Letras, 1998.

KOECHLIN, Bernard. Techniques corporelles et leur notation symbolique. Langages, Paris, $\mathrm{n}^{\circ} 10$, Pratiques et langages gestuels. (p. 36-47)

LE GOFF, Jacques. Rei. In: LE GOFF, J. e SCHMITT, J-C. Dicionário temático do ocidente medieval. Vol. 1. Bauru: Edusc; São Paulo: Imprensa Oficial, 2002. (p. 395-414)

LE GOFF Jacques.; TROUNG Nicholas. Uma história do corpo na Idade Média. 3a edição. Trad. Marcos Flamínio Peres. Rio de Janeiro : Civilização Brasileira, 2011.

MAUSS, M. Les techniques du corps. In: MAUSS, M. Sociologie et anthropologie. Paris: Presses Universitaires, 1960. (p. 365-386)

NIETZSCHE, Friedrich. Genealogia da moral. São Paulo: Companhia das Letras, 1998.

PÊCHEUX, Michel. Delimitações, inversões, deslocamentos. In: ORLANDI, E. P. e GERALDI, João Wanderley. (Org.) Cadernos de estudos lingüísticos. Campinas/IELUNICAMP, 1990. (p. 07-24)

PÊCHEUX, Michel. Discurso: estrutura ou acontecimento. 2. ed. Campinas: Pontes, 1997.

PIOVEZANI, Carlos. Política midiatizada e mídia politizada: fronteiras mitigadas na pósmodernidade. In: GREGOLIN, M. R. V. Discurso e mídia: a cultura do espetáculo. São Carlos: Claraluz, 2003. (p. 49-64)

ROUSSEAU, Jean-Jacques. Ensaio sobre a origem das línguas no qual se fala da melodia e da imitação musical. In: Rousseau. Vol. I. São Paulo: Nova Cultural, 1999. (Coleção Pensadores) (p. 259-332) 
SCHMITT, Jean-Claude. A moral dos gestos. In: SANT'ANNA, D. B. (Org.) Políticas do corpo. São Paulo: Estação Liberdade, 1995. (p. 141-161)

SENNET, Richard. O declínio do homem público: as tiranias da intimidade. São Paulo: Companhia da Letras, 1988.

Record, 2003.

A carne e a pedra: corpo e cidade na civilização ocidental. 3. ed. Rio de Janeiro:

SOUZA, Pedro. Dentro e fora: violência e irrupção urbana em cidades médias. In: Escritos (Percursos sociais e sentidos nas cidades). Campinas, $\mathrm{n}^{\circ} 1$, sd. (p. 11-16) 